\title{
Cambio de paradigma en el tratamiento del alcoholismo de baja gravedad
}

\section{A change of paradigm in the tretment of low-severity alcohol- dependent patients}

| Josep GuardiA-SerecignI
Unidad de Conductas Adictivas, Servicio de Psiquiatría. Hospital de la Santa Creu i Sant Pau. Barcelona (España).

Enviar correspondencia a:

Josep Guardia-Serecigni

Unidad de Conductas Adictivas. Servicio de Psiquiatría.

Hospital de la Santa Creu i Sant Pau

C/ Sant Antoni Maria Claret n $167 \cdot 08025$ - BARCELONA · SPAIN

Tels: +34-935-537-665 or +34-935-537-664

FAX: +34-935-537-666

E-mail: jguardia@santpau.cat

recibido: enero 2011 aceptado: julio 2011

\section{RESUMEN}

\section{Introducción}

Los avances en farmacoterapia del alcoholismo podrian propiciar un cambio de paradigma, basado en los nuevos programas de reducción del consumo de alcohol.

\section{Material y Método}

Este estudio revisa los fundamentos neurobiológicos y farmacoterapéuticos del alcoholismo, centrándose en los antagonistas opioides, el tratamiento orientado a la abstinencia y el orientado hacia la reducción del consumo de alcohol.

\section{Resultados}

1. Los programas de tratamiento de la dependencia del alcohol presentan sólo una eficacia pequeña o moderada.

2. Los pacientes presentan una elevada motivación para reducir el consumo de alcohol pero una baja motivación para abandonar de manera continuada al consumo de alcohol.

3. El programa de reducción continuada del consumo de alcohol, asociado a un tratamiento intermitente con naltrexona, puede ser de utilidad en los pacientes con una baja gravedad de la dependencia del alcohol.

\section{Discusión}

Aunque los pacientes que presentan una grave dependencia del alcohol deberían ser tratados en programas orientados hacia la abstención continuada, los que presentan una baja gravedad pueden beneficiarse de los programas de reducción del consumo de alcohol, los cuales pueden conseguir a corto plazo una reducción el número de consumiciones por día de consumo y, a largo plazo, incluso una progresiva reducción de la "obsesión" por beber, la conducta de búsqueda de alcohol y los trastornos médicos, conductuales y sociales, causados por el consumo excesivo de alcohol.

Para poder llevar a cabo este cambio de paradigma en el tratamiento del alcoholismo, se requieren futuros ensayos clínicos controlados para evaluar su eficacia y su tolerabilidad.

Palabras clave: Farmacoterapia del alcoholismo, reducción continuada del consumo de alcohol, antagonistas de los receptores opioides, dependencia del alcohol de baja gravedad, consumo de alcohol de bajo riesgo.

\section{ABSTRACT}

\section{Introduction}

Recent pharmacotherapy findings from new alcohol reduction programmes could change the paradigm of alcohol-dependence treatment.

\section{Material and Method}

This study reviews the neurobiological background and pharmacotherapy of alcohol-dependence disorder, focusing on opioid receptor antagonists, abstinence-oriented treatment and moderation-oriented treatment.

\section{Results}

1. Alcohol-dependence treatment programs show only low to moderate efficacy.

2. Patients usually show low motivation to sustain abstinence but high motivation to reduce alcohol use.

3. A treatment program based on continued reduction of drinking and associated with intermittent treatment with naltrexone can be useful for low-severity alcohol-dependent patients.

\section{Discussion}

Although high severity alcohol-dependent patients should stop drinking alcohol, low severity patients may have the option of reducing their alcohol consumption if they take an opioid antagonist medication every day that they decide to drink alcohol.

In the short term, the continuing drinking-reduction programmes may reduce the number of drinks per drinking day and in the long term, they may progressively decrease the obsession for drinking, alcohol seeking behavior, and related medical, behavioral and social disorders.

To change the paradigm in the treatment of alcohol-dependence disorder there is a need for further randomized controlled trials in order to assess their efficacy and tolerability.

Key words: Alcoholism pharmacotherapy, sustained reduction of alcohol consumption, opioid receptor antagonist medications, low alcoholdependence severity, low risk drinking. 


\section{INTRODUCCIÓN}

D os de cada tres personas que presentan dependencia del alcohol recaen en el consumo excesivo de alcohol semanas o meses después del inicio de su recuperación ${ }^{1,2}$. Los programas de tratamiento convencionales, orientados hacia la abstención continuada de alcohol y la toma diaria de la medicación consiguen sólo un tamaño del efecto pequeño o moderado, sin embargo, las evidencias de la investigación preclínica sugieren que otros programas de tratamiento, orientados hacia la reducción continuada del consumo de alcohol, puede resultar útiles para los pacientes con una baja gravedad de la dependencia.

Cuando el paciente alcohólico inicia el tratamiento no suele tener una expectativa de abstención continuada, sino de reducción del consumo de alcohol. Incluso cuando el paciente afirma que se propone dejar de beber suele tener la expectativa de algún consumo ocasional, en determinadas ocasiones (fiestas, celebraciones, vacaciones, comidas de trabajo o si algún día necesita tranquilizarse o bien afrontar alguna situación difícil). El problema es que cuando reaparece la pérdida de control, tanto el paciente como sus familiares pueden perder la confianza en el tratamiento.

El tratamiento orientado a la reducción del consumo de alcohol no es útil para cualquier paciente alcohólico. Sólo los pacientes bien motivados, de baja gravedad y que toman fármacos antagonistas de los receptores opioides pueden beneficiarse de esta modalidad de tratamiento.

La conexión neurobiológica entre el funcionalismo del sistema opioide y el consumo de alcohol se conoce desde hace más de tres décadas. Los estudios preclínicos han aportado muchas evidencias científicas, algunas de las cuales se han confirmado posteriormente en humanos. Algunos ensayos de laboratorio, efectuados en bares experimentales, nos ayudan a comprender el mecanismo de acción de los fármacos antagonistas de los receptores opioides y muchos ensayos clínicos de tratamiento del alcoholismo han evaluado la eficacia y la tolerabilidad de naltrexona y nalmefene para el tratamiento de la dependencia del alcohol y también para la reducción del consumo en personas que presentaban un consumo excesivo de alcohol ("heavy drinking").

Durante la última década, algunos estudios han utilizado dosis más elevadas y una administración intermitente de naltrexona y nalmefene, lo cual introduce la posibilidad de un cambio de paradigma en el tratamiento del alcoholismo de poca gravedad. Es decir, para aquellos pacientes que no presentan signos de abstinencia del alcohol ni tampoco trastornos médicos, psiquiátricos o adictivos comórbidos.

\section{NEUROBIOLOGÍA DEL ALCOHOLISMO Y NEUROADAPTACIÓN AL ALCOHOL}

El alcoholismo es una enfermedad adictiva, probablemente asociada a un mal funcionamiento de determinados circuitos cerebrales que intervienen en el auto-control de la conducta de ingerir bebidas alcohólicas. Se caracteriza por los aspectos incentivo-motivacionales del consumo de

\section{INTRODUCTION}

T wo our of three alcohol-dependent patients start drinking again within the first weeks or months of recovery ${ }^{1,2}$. Conventional treatment approaches, oriented towards sustained alcohol abstinence and daily opioid antagonist medication have achieved only low to moderate results. However, evidence from preclinical research suggests that other treatment approaches, aimed at sustaining reduction in alcohol drinking, could be useful for low severity patients.

When alcohol-dependent patients start treatment, their expectations are to reduce drinking rather than achieve continuous abstinence. When asked to freely explain their recovery plan they usually reply they are prepared not to drink most days but would like to have the possibility to have a drink on some occasions, such as holidays, celebrations, work meetings or special days when they need to relax or cope with difficult situations. The problem is that when loss of control over drinking reappears patients and their relatives may lose confidence in the treatment.

Treatment oriented towards reducing drinking is not useful for all alcohol-dependent patients. Only highly motivated, low severity, alcohol-dependence patients taking opioid antagonist medications may benefit from this modality of treatment.

The connection between opioid system function and alcohol consumption has been known for more than three decades. Preclinical studies have provided much scientific evidence, some of which has been useful in helping heavy drinkers. A number of clinical trials, performed in experimental bars, have helped to understand the mechanism of action of opioid receptor antagonists, and several clinical trials concerning treatment of alcoholism have assessed the efficacy and tolerability of naltrexone and nalmefene in alcohol-dependence treatment, and the reduction of alcohol consumption in heavy drinkers.

During the last decade, some studies have tried higher doses and intermittent administration of naltrexone and nalmefene. Such research has raised the possibility for a change of paradigm in the treatment of alcoholdependence for low severity patients, those without alcohol withdrawal signs, and those without clinically significant medical, psychiatric or addictive comorbidities.

\section{NEUROBIOLOGY OF ALCOHOLISM AND NEUROADAPTION TO ALCOHOL}

Alcohol-dependence is an addictive disease that is probably associated with a disorder of some brain circuits governing the self-control of alcohol drinking behavior. It is characterized by incentive motivational aspects of drinking 
alcohol y sus estímulos condicionados, pero también por el deterioro en la capacidad de inhibición de respuestas inapropiadas $^{3,4}$. Si no se detiene el curso de esta enfermedad pueden aparecer sus consecuencias médicas, psiquiátricas y adictivas, las cuales contribuyen a una mayor vulnerabilidad hacia la recaída y a su cronificación.

La administración aguda de alcohol produce una facilitación de la actividad inhibitoria del GABA, que sumada a una reducción de la actividad excitatoria del glutamato, los canales de calcio y la noradrenalina, generan un estado de enlentecimiento del Sistema Nervioso Central (SNC), que en un grado extremo de intoxicación (alcohólica) puede llegar a producir el coma y la muerte por parada cardio-respiratoria.

Sin embargo, la administración crónica de alcohol produce cambios neuroadaptativos compensatorios a los de su administración aguda, que generan un estado de hiperexcitabilidad del SNC, que puede expresarse clínicamente a través de los sintomas de abstinencia y que es debido tanto a una hiperfunción glutamatérgica, noradrenérgica y de los canales de calcio, como a una hipofunción gabérgica.

En el Área Tegmental Ventral (ATV) del mesencéfalo, las neuronas dopaminérgicas se encuentran sometidas al control tónico inhibitorio de las neuronas GABA y éstas, a su vez, pueden ser activadas por la neurona glutamatérgica o frenadas por la neurotransmisión opioidérgica. La función de estos sistemas de neurotransmisión, que confluyen en la encrucijada del ATV, puede jugar un papel decisivo en las recaídas.

Cuando el paciente alcohólico deja de beber, suele presentar un bajo funcionamiento de su neurotransmisión dopaminérgica (hipodopaminergia), pero un nuevo consumo de alcohol va a producir una gran liberación de dopamina en regiones mesolímbicas, (debido al efecto agudo del alcohol sobre la neurotransmisión glutamatérgica, opioidérgica y gabérgica) que puede disparar estados de craving, búsqueda y consumo de alcohol ${ }^{5}$.

El alcohol, en administración aguda, produce liberación de opioides endógenos, sobretodo beta-endorfinas, las cuales van a dar lugar a un aumento de la liberación de dopamina en el núcleo accumbens, (mediado por su acción inhibitoria sobre las neuronas GABA del ATV). Dicho incremento en la disponibilidad de dopamina puede tener relación con su efecto reforzador positivo, el craving y la pérdida de control que pueden llevar a la recaída. Por tanto, determinados fármacos que actúen sobre estos sistemas de neurotransmisión podrán modular las mencionadas alteraciones y reducir el riesgo de recaída.

Por otro lado, un paciente dependiente del alcohol puede presentar sintomas de rebote o abstinencia, cuando lleva unas horas sin ingerir alcohol, y puede experimentar un poderoso efecto reforzador negativo de un nuevo consumo de alcohol o de benzodiazepinas (BZD) ya que ambos pueden neutralizar, de manera rápida y eficaz, los sintomas de abstinencia. Por tanto, el alcohol puede tener un doble efecto reforzador, el positivo relacionado con la liberación de endorfinas (que secundariamente producen desinhibición de las neuronas dopaminérgicas del ATV) y el negativo, en relación con su capacidad de aliviar la abstinencia del alcohol and its conditioned cues, and also by the impaired ability of inhibition of inappropriate responses ${ }^{3,4}$. If the course of this disease is not stopped, the medical, psychiatric and addictive consequences can progressively worse, thereby increasing vulnerability to relapse and the drift to its chronicity.

Acute alcohol administration facilitates inhibitory activity of GABA neurotransmission. In association with a reduction of the excitatory activity of glutamate, calcium channels and norepinephrine, this produces a slowing of the Central Nervous System (CNS). When intoxication is severe, this can lead to coma and death due to cardio-respiratory failure.

Chronic alcohol administration, however, induces compensatory neuro-adaptive changes opposite to those of acute administration. These changes produce a hyperexcitability state of the CNS. This state can become clinically apparent from the presence of withdrawal signs, and may be the consequence of a hyperfunction of glutamatergic, norepinephrinergic and calcium channels, as well as hypofunction of GABAergic neurotransmission.

In the midbrain Ventral Tegmental Area (VTA), dopaminergic neurons are controlled by tonic inhibition of GABA neurons that can be activated in turn by glutamatergic neurotransmission or inhibited by the activation of opioidergic neurotransmission. The function of these neurotransmission systems, which come together in this VTA crossroad, can play a decisive role in relapse.

When alcohol-dependent patients stop drinking, their dopaminergic neurotransmission usually functions slowly, leading to a hypodopodopaminergic state. However, renewed alcohol consumption will cause a high release of dopamine in the mesolimbic regions because of the acute effect of alcohol on glutamatergic, opioidergic and gabergic neurotransmission ${ }^{5}$.

Acute alcohol intake causes a release of endogenous opioids, mostly beta-endorphines, that have an inhibitory action on GABA neurons, inducing a secondary release of dopamine in the nucleus accumbens. This dopamine release can be associated with a positive reinforcing effect, an increase in alcohol craving, and also loss of control, that can drive the patient to relapse. Therefore, some medications that act on these neurotransmission systems may modulate their function, thereby reducing the relapse risk.

Withdrawal symptoms may also play an important role in vulnerability to relapse. After not drinking alcohol for a few hours, renewed alcohol consumption can induce a powerful negative reinforcing effect in an alcohol-dependent person because he or she can quickly neutralize withdrawal symptoms. Alcohol can therefore have a double reinforcing effect: a positive effect related to endorphine release (that subsequently causes dopamine release), and a negative effect related to its ability to alleviate alcohol withdrawal 
y también determinados síntomas, como ansiedad, dificultad en conciliar el sueño, tensión, disforia, fobias, estrés postraumático $u$ otros 6 .

\section{CONSUMO DE RIESGO Y GRAVEDAD DE LA DEPENDENCIA DEL ALCOHOL}

El consumo de alcohol inferior a $40 \mathrm{gr} /$ día para los hombres, $20 \mathrm{gr} /$ día para mujeres, cuando es muy frecuente, se considera como un consumo de bajo riesgo, porque ya puede estar asociado a determinadas consecuencias negativas. Un consumo entre 40 y $60 \mathrm{gr} /$ día para los hombres (entre 20 y $40 \mathrm{gr} /$ día para las mujeres) se considera de riesgo moderado. Entre 60 y $100 \mathrm{gr} /$ día para los hombres (entre 40 y $60 \mathrm{gr} / \mathrm{dia}$ para las mujeres) se considera de riesgo elevado y por encima de los $100 \mathrm{gr} /$ día para los hombres y de los $60 \mathrm{gr} /$ día para las mujeres, de riesgo muy elevado ${ }^{7,8}$.

Los ensayos clínicos de tratamiento del alcoholismo con naltrexona han utilizado el criterio de "heavy drinking" que consiste en la ingesta de 5 o más consumiciones por ocasión, (4 o más en mujeres) como criterio de recaída, ya que existen evidencias de que superar este umbral de consumo va asociado a consecuencias negativas ${ }^{9}$. Además, estudios recientes han confirmado la relación entre el número de días que el paciente supera dicho límite y la cantidad de consecuencias negativas del consumo de alcohol ${ }^{10}$.

Beber hasta la embriaguez, que es lo que suele ocurrir cuando el patrón de consumo es en forma de "atracones" de bebida ("binge drinking"), produce un efecto de deterioro de la capacidad de razonamiento, la toma de decisiones y la capacidad de auto-control del comportamiento. En tal estado, la persona presenta desinhibición de impulsos sexuales y agresivos que favorecen la aparición de discusiones, peleas, agresiones, relaciones sexuales no planificadas o no deseadas ${ }^{11}$. Además, el deterioro de la coordinación motora puede ser la causa de accidentes y lesiones ${ }^{12}$, incluso por caídas en la calle, en el trabajo ${ }^{13}$ o en el propio hogar. Cuando el consumo excesivo se produce de manera regular y frecuente, las consecuencias negativas van a ser las de su toxicidad cróni$c a$ es decir los trastornos médicos y neuro-psiquiátricos ${ }^{14}$.

La gravedad de la dependencia del alcohol presenta un amplio rango de intensidades, desde una muy baja gravedad muy parecida al consumo de riesgo de alcohol, hasta una muy alta gravedad parecida a la de la adicción a la heroína por vía intravenosa o la cocaína "crack". Un alcoholismo de baja gravedad se caracteriza por cierta dificultad para controlar el consumo de alcohol, lo cual puede ser solamente un problema ocasional o intermitente. La presencia de abstinencia aguda del alcohol o de trastornos médicos, psiquiátricos 0 adictivos comórbidos al alcoholismo pueden ser indicadores de una elevada gravedad de la dependencia del alcohol. Probablemente, la mayoría de pacientes alcohólicos presentan una baja o moderada gravedad y el síndrome de abstinencia puede estar presente sólo en un 20\% de los pacientes dependientes del alcohol, pero suele ser un signo de elevada gravedad de la dependencia ${ }^{15}$. and also symptoms such as anxiety, difficulty in falling asleep, tension, dysphoria, phobias, or posttraumatic stress ${ }^{6}$.

\section{DRINKING RISK AND ALCOHOL-DEPENDENCE SEVERITY}

Drinking even less than $40 \mathrm{gr} /$ day for men or 20 gr/day for women has been associated with negative consequences, and can thus be considered low risk drinking. Between 40 and $60 \mathrm{gr} /$ day for men (between 20 and $40 \mathrm{gr} /$ day for women) is considered moderate risk drinking. Between 60 and $100 \mathrm{gr} /$ day for men (between 40 and $60 \mathrm{gr} /$ day for women) is considered high risk drinking, and over $100 \mathrm{gr} /$ day for men and over $60 \mathrm{gr} /$ day for women is considered a very high risk drinking ${ }^{7,8}$.

Alcohol-dependence clinical trials have used the concept of heavy drinking day, the equivalent of 5 or more drinks per drinking day (4 or more for women), as a relapse criterion. There is evidence that some negative consequences are probable above this limit $^{9}$ and recent clinical trials have confirmed that drinking over this threshold is associated with negative consequences during treatment and also during follow-up (after treatment has ended) ${ }^{10}$.

Drinking to drunkenness, usually the consequence of a binge-drinking pattern of alcohol consumption, causes impairments to judgment, decision making and behavioral self-control. Under acute alcohol intoxication people may show sexual and aggressive impulse disinhibition that favors arguments, fights, aggression, non-planned or undesired sexual relationships ${ }^{11}$. Accidents, injuries ${ }^{12}$ and even falls in the street or at work or at home ${ }^{13}$ may result from motor coordination impairment.

Chronic heavy drinking is associated with medical and neuro-psychiatric diseases related to chronic alcohol toxicity ${ }^{14}$.

Alcohol-dependence severity ranges in intensity from a very low severity, similar to heavy drinking, to very high severity, similar to intravenous heroin or crack cocaine dependence. Low severity alcohol-dependence is characterized by some kind of difficulty in alcohol drinking control that can be even an intermittent or occasional problem. Signs of high alcohol-dependence severity may be the presence of acute alcohol withdrawal or other comorbidities, such as medical diseases, psychiatric disorders or addictive disorders associated with alcoholdependence disorder. Most alcohol-dependence patients show a low to moderate severity, and a withdrawal syndrome may only be present in about $20 \%$ of alcoholdependent patients, usually being a sign of a severe alcohol-dependence ${ }^{15}$. 


\section{TRATAMIENTO FARMACOLÓGICO DEL ALCOHOLISMO}

Cuando un paciente alcohólico consigue reducir su consumo (de alcohol), o bien dejar de beber durante una temporada, se recupera rápidamente de las consecuencias debidas a la toxicidad crónica del alcohol pero los estímulos condicionados pueden disparar estados de "craving" (o deseo imperioso de beber) que van a conducir a un nuevo consumo (de alcohol), tras el cual reaparece la dificultad para controlar o incluso la pérdida de control, que pueden llevarle a la recaída. Aunque algunas personas consiguen dejar de beber durante largas temporadas $\sin$ ayuda, otros necesitan un tratamiento especializado que neutralice su tendencia hacia la recaída ${ }^{16}$.

Cuando la dependencia del alcohol es grave, la dificultad para controlar el consumo es extrema, los estímulos condicionados gobiernan la conducta de beber alcohol y se produce una "robotización" de dicha conducta, de manera que la persona expuesta a determinados estímulos condicionados no puede evitar el consumo de alcohol $y$, una vez iniciado dicho consumo, tendrá serias dificultades para detenerl $0^{17,6}$. Sin embargo, la mayoría de personas que presentan dependencia del alcohol tienen un alcoholismo de baja gravedad, que en algunas personas se manifiesta sólo de manera intermitente, con episodios ocasionales de consumo descontrolado, que se alternan con un consumo más moderado o con abstención de alcohol.

Los pacientes alcohólicos de baja gravedad también pueden sufrir las consecuencias médicas, psiquiátricas, familiares y legales del consumo excesivo de alcohol, también pueden intentar reducir o suprimir el consumo de bebidas alcohólicas. Sin embargo, tras unos días sin beber, pueden empezar de nuevo y pueden reaparecer sus consecuencias negativas. La dependencia del alcohol puede sufrir un agravamiento progresivo y llegar a convertirse en una enfermedad crónica y recidivante que puede destruir la salud, la familia y el hogar. Cuando una persona ha perdido dichos recursos sus posibilidades de recuperación disminuyen.

La detección precoz y el tratamiento especializado de los pacientes alcohólicos de baja gravedad es importante para detener su probable evolución hacia un empeoramiento progresivo. Diversos fármacos -disulfiram, acamprosato o naltrexona- $y$ también diversas intervenciones psico-sociales han demostrado su eficacia y también su buena relación costeeficacia para el tratamiento del alcoholismo, pero los médicos todavía prescriben con más frecuencia antidepresivos y benzodiazepinas a los pacientes alcohólicos ${ }^{18}$.

En los años 70 se desarrollaron intervenciones psicológicas orientadas hacia el consumo controlado (de alcohol), pero en la década de los 80 quedaron bastante desprestigiados ante la comunidad científica, dado que sus resultados iniciales fueron pobres, particularmente para los pacientes alcohólicos más graves. En efecto, estos pacientes graves necesitan un programa de tratamiento orientado hacia la abstinencia continuada de alcohol, sin embargo, la mayoría de personas que tienen alcoholismo no presentan una grave

\section{PHARMACOLOGICAL TREATMENT OF ALCOHOLISM}

When alcohol-dependent patients succeed in reducing or stopping alcohol consumption during a period, they can quickly recover from the consequences of chronic alcohol toxicity but conditioned cues will shoot craving states that will drive them to renew alcohol consumption. These craving states are associated with loss of control and relapse, closing the circle of addiction, and characterized by seasons of remission and relapse crisis. Although some people can stop drinking for long periods of time without help, others need specialized treatment to overcome their proneness to relapse ${ }^{16}$.

When an alcohol-dependence disorder is severe, impaired control over consumption may be extreme, and conditioned cues may govern drinking behavior, which may become "robotized". When the severe alcohol-dependent patient is exposed to specific cues he might be dragged down to drinking and, when he starts drinking again, he will have serious difficulties to stop ${ }^{17,6}$. However, most alcoholdependent patients probably show low severity, and many only have intermittent problems, with occasional difficulties in controlling drinking (not everyday) alternating with periods of moderation or sobriety.

Low severity alcohol-dependent patients may also suffer the medical, psychiatric, familial and legal consequences of excessive drinking, and they may try to reduce or stop alcohol consumption. However, after some days of abstinence, they will start drinking again and negative consequences will reappear. Alcohol-dependence can progressively become a chronic and relapsing disease that can destroy health, family and home. When a person has lost all these resources, their recovery possibilities are poorer.

Early detection and specialized treatment of low severity alcohol-dependent patients is therefore important to avoid progressive worsening. Several specialized medications and several psycho-social interventions have proven useful and cost-effective treatments for alcohol-dependence disorder. However, instead of prescribing specific medications that have proven efficacy in alcohol-dependence treatment - such as disulfiram, acamprosate or naltrexone physicians tend to prescribe antidepressive medications or benzodiazepines ${ }^{18}$.

Controlled drinking interventions were developed during the 70s, but they were criticized and discredited by the scientific community in the 80 s because of their poor initial results, particularly in more severe patients. Indeed, these severe patients require an abstinence-oriented treatment program, but low severity alcohol-dependent patients can benefit from an intervention oriented to sustained reduction of drinking. 
dependencia y pueden beneficiarse de las intervenciones orientadas hacia la reducción continuada de alcohol.

El estudio COMBINE, efectuado en Estado Unidos ${ }^{19}$, compara diversas modalidades de tratamiento farmacológico y psico-social del alcoholismo y concluye que uno de los indicadores más útiles del resultado del tratamiento es el número de dias de consumo excesivo ("heavy drinking days") que ha tenido el paciente a lo largo de todo el tratamiento, ya que este indicador tiene una buena correlación con la cantidad de consecuencias (relacionadas con el consumo de alcohol) que ha sufrido cada paciente durante el tratamiento e incluso durante su seguimiento posterior ${ }^{10}$. Esta correlación sugiere que si un paciente consigue mantener un consumo de alcohol que no alcance las 5 consumiciones en un día (si es un hombre), 4 si es una mujer, presentaría prácticamente la misma cantidad de consecuencias negativas, (relacionadas con el consumo excesivo de alcohol), que la persona que ha dejado de tomar bebidas alcohólicas.

Dicho de otra manera, no beber alcohol todos los días y no alcanzar el límite del consumo excesivo de alcohol en cada ocasión de beber, se podría considerar también como remisión clínica si no va asociada a posibles consecuencias negativas. Por lo tanto, los abordajes terapéuticos orientados hacia la reducción continuada del consumo de alcohol, con la ayuda de un antagonista de los receptores opioides, podría ser una alternativa satisfactoria al abordaje convencional orientado hacia la abstinencia del alcohol.

\section{Tratamiento farmacológico de la prevención de recaídas}

En un cerebro neuroadaptado al alcohol, el tono dopaminérgico basal está disminuido pero un nuevo consumo de alcohol va a producir una importante activación dopaminérgica, debida al efecto de liberación de opioides endógenos que, actuando sobre las neuronas GABA del ATV van a producir una desinhibición de las neuronas dopaminérgicas ${ }^{5,20}$ y dichos cambios en determinados sistemas de neurotransmisión están directamente relacionados con los síntomas de la conducta adictiva, tales como la dificultad para controlar y el craving.

Los estudios efectuados sobre la farmacoterapia del alcoholismo han comprobado que ni los agonistas ${ }^{21}$ ni los antagonistas de los receptores dopaminérgicos ${ }^{22,23}$ consiguen una eficacia superior a placebo para la prevención de recaídas. Los agonistas de los receptores GABA-A pueden ser de utilidad para la prevención y el tratamiento del síndrome de abstinencia aguda del alcohol, pero presentan bastantes inconvenientes y también algunos riesgos (dependencia y sobredosificación), cuando el tratamiento se prolonga más allá de la fase aguda de la abstinencia. Determinados antagonistas GABA-B, como el baclofeno, podrían ser de utilidad, tanto durante la abstinencia aguda como para reducir el craving de alcohol, pero se requieren más estudios que confirmen su eficacia y su tolerabilidad. Determinados fármacos anticomiciales que tienen efectos antiglutamatérgicos y favorecedores de la neurotransmisión GABA podrian ser de
Performed in the USA the COMBINE study ${ }^{19}$ compares several modalities of alcohol-dependence treatment. It suggests that one of the most useful indicators of treatment outcome is the percentage of heavy drinking days, because this variable shows a good correlation with the number of alcohol-related consequences each patient has suffered (either during treatment or even during the subsequent follow-up $)^{10}$. This correlation suggests that if patients manage to drink fewer than 5 drinks for men (fewer than 4 for women), and do not drink everyday, they will not have more alcohol-related adverse consequences than patients that maintain their sobriety.

In other words, not drinking every day and not reaching the level of heavy drinking (on any drinking occasion) could also be considered sustained remission because it is not expected to be associated with alcoholrelated negative consequences. Therefore, therapeutic approaches for low-severity patients, oriented towards a sustained reduction in alcohol drinking, could be a satisfactory alternative to conventional abstinenceoriented approaches.

\section{Relapse prevention pharmacotherapy}

As explained earlier, basal dopaminergic tone is usually decreased in an alcohol neuro-adapted brain, but a new alcohol consumption will produce a marked dopaminergic activation related to craving, loss of control and relapse $e^{5,20}$. In the midbrain VTA crossroad, dopaminergic neurons activity is influenced by opioidergic, glutamatergic and gabergic neuron activity, all of which are modified by acute alcohol consumption. Medications that modulate the functioning of these neurotransmitter systems may be useful for alcoholdependence pharmacotherapy.

Studies on the pharmacotherapy of alcoholism have shown than neither dopaminergic agonists ${ }^{21}$ nor antagonists ${ }^{22,23}$ obtain greater efficacy than placebo in relapse prevention treatment. GABA-A agonists can be useful for withdrawal prevention and treatment, but they present some drawbacks and also risks (of overdose and addiction) when their treatment goes beyond the acute abstinence phase. Some GABA-B agonists, such as baclofen, may be useful either during acute abstinence or for the treatment of the alcohol craving, but other studies confirming its efficacy and tolerability are warranted. Some anticonvulsants with antiglutamatergic effects that can favor GABA neurotransmission could be useful even for alleviating symptoms of alcohol protracted withdrawal ${ }^{17,24}$, but other studies confirming its efficacy and tolerability are warranted.

Disulfiram is a medication that has been used for more than 40 years in the treatment of alcoholism. Orally administered in doses of $250 \mathrm{mg} /$ day it produces a 
utilidad incluso para aliviar los sintomas de abstinencia postaguda ${ }^{17,24}$, pero también se requieren más estudios que confirmen su eficacia y su tolerabilidad.

El disulfiram es un fármaco que se ha venido utilizando desde hace más de 40 años para el tratamiento del alcoholismo. Se administra por vía oral, en dosis de $250 \mathrm{mg} / \mathrm{dia}$. Produce un bloqueo de la enzima aldehído-deshidrogenasa (ALDH) que interfiere en el metabolismo del alcohol y que causa una acumulación de acetaldehído, que va a producir efectos desagradables e incluso peligrosos a la persona que toma bebidas alcohólicas (tras haber tomado disulfiram). Por tal motivo tiene unas indicaciones limitadas, diversas contraindicaciones y requiere una evaluación del estado físico y mental, previa al inicio del tratamiento y también periódica a lo largo de su tratamiento. La cianamida cálcica produce un efecto parecido pero su efecto de bloqueo de la ALDH es menos duradero que el del disulfiram y requiere administración cada 12 horas. Dichos fármacos se utilizan en programas orientados hacia la abstinencia completa y continuada de alcohol, pero las reacciones acetaldehídicas tienen riesgos que pueden llegar a ser graves para personas que tienen una salud precaria y están contraindicados en dichas personas. Además, muchos pacientes rechazan el tratamiento con disulfiram o cianamida, ya que conservan la expectativa de poder hacer algún consumo ocasional de alcohol. Tarde o temprano muchos pacientes dejan de tomar estos fármacos y si prueban de volver a tomar bebidas alcohólicas, la recaída es muy probable 4 .

\section{Los antagonistas opioides en el tratamiento del alcoholismo}

Naltrexona es un antagonista opioide de semivida larga y buena absorción oral que produce una disminución del efecto reforzador y también del consumo de alcohol, tanto en estudios efectuados con animales adiestrados para beber alcohol en exceso, como en los pacientes que presentan dependencia del alcohol ${ }^{25}$. Su dosis habitual, para el tratamiento de la dependencia del alcohol, es de $50 \mathrm{mg} /$ día sin embargo el estudio COMBINE ha empezado a utilizar dosis diarias de 100 $\mathrm{mg}$, durante 16 semanas de tratamiento ${ }^{19}$.

Tanto los estudios preclínicos como los efectuados en un bar experimental han comprobado que naltrexona produce una reducción del consumo de alcohol por ocasión, es decir, del número de consumiciones tomadas y además consigue una reducción progresiva del consumo ${ }^{26,27}$.

En estudios de laboratorio, efectuados en un bar experimental con personas que presentaban un consumo excesivo de alcohol y que no deseaban hacer tratamiento del alcoholismo, naltrexona consiguió una disminución del efecto reforzador positivo del alcohol, de la urgencia por beber, del número de consumiciones tomadas, de la velocidad de consumo de alcohol y un posible incremento de efectos no deseados de la intoxicación alcohólica, tales como cefalea o náuseas, en comparación a placebo ${ }^{28}$. Y, tanto naltrexona 50 $\mathrm{mg} /$ día como nalmefene $40 \mathrm{mg} / \mathrm{di}$, consiguen una supresión blocking effect of the aldehyde-deshydrogenase enzyme that interferes with the alcohol metabolism causing an accumulation of acetaldehyde, and producing unpleasant and even dangerous effects when the patient drinks alcohol. Therefore, it has limited indications and some counterindications. It requires an assessment of the physical and mental state before treatment begins and periodical assessment throughout its treatment. Calcium cyanamide produces similar effects but it has a shorter duration than disulfiram and it requires twice-daily administration. These medications are useful in treatment programs oriented towards sustained alcohol abstinence but there is risk of dangerous reactions, especially for patient with poor health status. Besides, many patients refuse treatment with disulfiram or cyanamide because they still have the expectation to drink alcohol occasionally. Sooner or later many patients stop taking these medications and alcohol relapse is very probable if they try to drink ${ }^{4}$.

\section{Opiod antagonists in the treatment of alcoholism}

Naltrexone is an opioid antagonist that has a long half-live and good oral absorption. It produces a decrease in alcohol reinforcing and consumption both in animal models of heavy drinkers and in alcohol dependent patients ${ }^{25}$. Their usual dose for alcohol-dependence treatment is $50 \mathrm{mg} / \mathrm{day}$, although the COMBINE study used a higher dose of $100 \mathrm{mg} /$ day $^{19}$.

Preclinical studies and human studies performed in an experimental bar have shown that naltrexone reduces total alcohol consumption and the number of drinks per drinking occasion and also progressively reduces subsequent drinking occasions ${ }^{26,27}$.

Laboratory studies performed in an experimental bar with heavy drinkers not seeking alcohol treatment have shown that naltrexone decreases the positive reinforcing effects of alcohol. This brings about a decrease in the urgency to drink (alcohol) and in the final number of alcohol drinks taken due to slower drinking. There is also a possible increase in the undesirable effects of alcohol intoxication, such as headache or nausea, in some people ${ }^{28}$. Both naltrexone $50 \mathrm{mg} /$ day and nalmefene $40 \mathrm{mg} /$ day can suppress the increased craving and stimulation effect of initial alcohol consumption ${ }^{27}$.

Naltrexone is efficacious in reducing alcohol consumption and preventing relapse to heavy drinking 29,30,19,31. Cochrane revisions confirm that oral naltrexone (50 mg/day, during 12 weeks) obtains a $36 \%$ reduction in relapse rate and reduces the number of drinking days, the number of heavy drinking days, total alcohol consumption, alcohol craving and gamma- 
del incremento del deseo de beber y del efecto de estimulación, tras un primer consumo de alcohol ${ }^{27}$.

Los estudios efectuados con naltrexona para el tratamiento del alcoholismo han determinado su eficacia para reducir el consumo de alcohol y la tasa de recaídas a los 3 meses de tratamiento $29,30,19,31$. Los metanálisis de Cochrane han confirmado que naltrexona (50 mg/dia, durante 12 semanas), obtiene una reducción del $36 \%$ en la tasa de recaídas y reduce el número de días de consumo de alcohol, de días de consumo excesivo de alcohol, el consumo total de alcohol, el craving y los niveles de gamma-glutamiltransferasa. Sin embargo, el tamaño del efecto es pequeño a moderado 32,33 .

En algunos estudios controlados naltrexona no ha demostrado ser superior a placebo $34,35,36$, sin embargo, un reanálisis de dos estudios negativos sugiere que naltrexona puede reducir el riesgo de un consumo excesivo y que aumenta la probabilidad de abstención de alcohol ${ }^{37}$.

Un buen cumplimiento en la toma de medicación puede ser decisivo para que la reducción de la tasa de recaídas o del craving alcancen la significación estadística, en comparación a placebo ${ }^{38}$. Por tanto, la eficacia del tratamiento aumenta si la administración es supervisada por una familiar o la enfermera, los cuales pueden hacer un seguimiento intensivo del paciente, con determinaciones periódicas de sustancias en la orina ${ }^{4}$.

En el estudio COMBINE, naltrexona oral a dosis de 100 $\mathrm{mg} /$ dia, durante 16 semanas, consigue un aumento del porcentaje de días de abstención (80,6\% vs. $75,1 \%$ ) y una reducción del riesgo de días de consumo excesivo de alcohol $(66,2 \%$ vs. $73,1 \%)$, en comparación a placebo. Además se utilizó el criterio que denominan "buen resultado clínico" y que definen como no más de 2 días de consumo excesivo de alcohol a la semana, un consumo máximo de 14 consumiciones/semana para los hombres (11 para las mujeres) y la ausencia de problemas significativos, relacionados con el alcohol, durante las últimas 8 semanas de las 16 totales de tratamiento $0^{19,39}$.

Los ensayos clínicos controlados con naltrexona para el tratamiento del alcoholismo han comprobado que entre los pacientes que bebieron durante el tratamiento, aquellos que tomaron naltrexona presentaron una menor incidencia de recaídas que los que no tomaron naltrexona, probablemente debido a que naltrexona puede prevenir que un consumo ocasional de alcohol se acabe convirtiendo en una recaída ${ }^{40}$; y que los pacientes que bebieron con mayor frecuencia fueron los más beneficiados por el tratamiento con naltrexona, ya que presentaron una menor porcentaje de días de consumo excesivo de alcohol ${ }^{41}$. Una menor gravedad de la dependencia y un consumo de alcohol más frecuente podrian ser predictores de una buena respuesta al tratamiento con naltrexona ${ }^{42}$, lo cual sugiere que naltrexona puede ser más útil en el contexto del beber controlado o de la reducción del consumo de alcohol que en el tratamiento orientado hacia la abstención continuada de alcohol. Una interpretación alternativa podría ser que naltrexona es más eficaz entre los pacientes alcohólicos de baja gravedad, que posiblemen- glutamiltranferase levels; however, the effect size is between low and moderate ${ }^{32,33}$.

In some controlled studies naltrexone has not proven superior to placebo ${ }^{34,35,36}$. However, the re-analysis of two negative studies suggests that naltrexone can reduce the risk for heavy drinking and increase the probability of alcohol abstinence ${ }^{37}$.

Good compliance with daily medication can be decisive to reach a significant efficacy in reducing the relapse rate or craving as compared to placebo ${ }^{38}$. The efficacy of naltrexone therefore increases if its administration is supervised by a relative or nurse who can conduct intensive follow-up with periodic determinations of substances in urine ${ }^{4}$.

In the COMBINE study, administration of $100 \mathrm{mg} /$ day oral naltrexone for 16 weeks increased the percentage of abstention days ( $80.6 \%$ vs. $75.1 \%$ in the placebo group), and reduced the risk of heavy drinking days (66.2\% vs. $73.1 \%$ in the placebo group). Furthermore, the authors used a "good clinical outcome" criterion; this was defined as no more than two days' heavy drinking a week, no more than 14 drinks/week for men (11 for women), and absence of significant alcohol-related problems over the last 8 weeks (from the total 16 weeks' treatment) ${ }^{19,39}$

Randomized controlled trials with naltrexone have shown that patients who drank alcohol but took naltrexone had a lesser incidence of relapses than those who did not take naltrexone. This is probably because naltrexone can prevent occasional consumption becoming a full relapse ${ }^{40}$, and because patients who drank more frequently benefited most from by naltrexone treatment because they showed a lower percentage of heavy drinking days ${ }^{41}$. In addition, lower severity of alcoholdependence and more frequent alcohol consumption could also be predictors of good response to naltrexone treatment ${ }^{42}$. Therefore, naltrexone could be useful in the context of a treatment program aiming to reduce drinking in low severity alcohol-dependence patients. These patients may possibly drink moderately more frequently and have less difficulty to control drinking.

In several studies the therapeutic effect of naltrexone did not reach statistical significance until the second month of treatment ${ }^{29,41,19,39}$. This suggests that the effect of naltrexone treatment could be progressive, and that the patient probably needs to repeat the experience of blocking the reinforcing effect of drinking before the benefit of the drug takes effect.

The most frequent adverse events of naltrexone are headache and nausea but dizziness, vomiting, pain or abdominal malaise, anorexia, fatigue, restlessness, insomnia and anxiety may appear in the first days of 
te conservan la capacidad de beber con mayor frecuencia y con menor dificultad para controlar el consumo. De hecho, los pacientes que bebieron durante el estudio COMBINE presentaban una menor gravedad y una mayor probabilidad de tener un objetivo personal de consumo controlado y en diversos estudios, el efecto terapéutico de naltrexona no alcanzó la significación estadística hasta el segundo mes de tratamiento $29,41,19,39$, lo cual sugiere que su efecto podría ser progresivo y que el paciente probablemente necesita repetir varias veces la experiencia de bloqueo del efecto reforzador del consumo de alcohol.

Los efectos adversos de naltrexona pueden afectar al $30 \%$ de los pacientes, siendo los más frecuentes náuseas y cefalea. Otros posibles efectos adversos son mareo, vómito, dolor o malestar abdominal, anorexia, astenia, inquietud, insomnio o ansiedad, que pueden aparecer los primeros días de tratamiento, suelen ser de intensidad leve y tienden a desaparecer $^{43}$. El inicio del tratamiento con una dosis menor (25 $\mathrm{mg} /$ día) y, acompañada por la comida, puede minimizar los efectos adversos y favorecer la adaptación progresiva del organismo, para llegar a alcanzar unos días después la dosis habitual de $50 \mathrm{mg} /$ dia. Sin embargo, el estudio COMBINE ha utilizado una dosis diaria de $100 \mathrm{mg}$, durante 16 semanas de tratamiento ${ }^{39}$.

El tratamiento con naltrexona tienen diversas contraindicaciones, tales como la presencia de una grave hepatopatía, la dependencia de opioides activa o el tratamiento con analgésicos opioides. Por este motivo requiere una analítica general previa y también la evaluación periódica del funcionalismo hepático. Una elevación de las transaminasas entre 4 y 5 veces por encima de su límite superior sería una contraindicación relativa de naltrexona y se recomienda la retirada del tratamiento con naltrexona 48 a 72 horas antes de una intervención quirúrgica, particularmente cuando es de cirugía mayor ${ }^{39}$.

La naltrexona inyectable de liberación prolongada puede tener una mayor eficacia que la naltrexona oral. Se administra una dosis de $380 \mathrm{mg}$ cada cuatro semanas y produce una reducción de los días de consumo excesivo de alcohol en un $25 \%$ y de las consumiciones tomadas los días en los que el paciente vuelve a beber. El inicio del efecto terapéutico podría ser muy rápido (desde el segundo día) y se mantendría a lo largo de todo el tratamiento, con lo cual podría facilitar el compromiso del paciente con el tratamiento y la intervención psicoterapéutica especializada ${ }^{44,45}$. Un estudio efectuado con 624 pacientes ha comprobado que naltrexona de liberación prolongada no tiene efectos hepatotóxicos, ni siquiera para los pacientes que siguieron bebiendo alcohol en exceso durante el tratamiento, consiguiendo una reducción de la GGT superior al placebo en las semanas 4, 8,12 y 20 de tratamiento ${ }^{46}$.

La eficacia del tratamiento con naltrexona ha sido comprobada también mediante estudios controlados, en pacientes que presentan comorbilidad con otros trastornos psiquiátricos. En un estudio controlado, efectuado con 31 pacientes esquizofrénicos, que presentaban además alcoholismo, naltrexona consigue una reducción tanto del consumo como del craving de alcohol ${ }^{47}$. En otro estudio controlado, treatment. These adverse events are present in 30\% of patients, they are usually of low severity and they have a tendency to disappear ${ }^{43}$. Beginning treatment with a low dose ( $25 \mathrm{mg} /$ day) and taking this with a meal can minimize the adverse events and favor progressive adaptation of the organism. Some days later, the dose can be increased to $50 \mathrm{mg} /$ day; the COMBINE study has used up to $100 \mathrm{mg} /$ day $^{39}$.

Naltrexone treatment has several counter-indications, such as severe liver disease, active opiate-dependence or pain-relieving treatment with opiate analgesics. For this reason, a baseline blood test with liver function should be performed before starting treatment. An increase of 4 to 5 times the liver enzymes may be a counter-indication of naltrexone treatment. However, two weeks of abstinence may achieve a substantial decrease in liver enzymes if there is no concurrent liver disease such as viral hepatitis. During naltrexone treatment, periodic assessments of liver function are recommended. A withdrawal of naltrexone 48 to 72 hours before a surgical intervention is recommended, especially in the case of major surgery ${ }^{39}$.

Slow release injectable naltrexone may be more effective than oral naltrexone because it achieves more stable serum levels of naltrexone for 4 weeks. Doses of $380 \mathrm{mg}$ every 4 weeks achieve a $25 \%$ reduction in heavy drinking days and drinks per drinking day, but differences have not reached statistical significance for women. A 14\% rate of abandonment due to adverse events has been reported, the most frequent events being nausea, headache, fatigue, insomnia, vomiting, anorexia, diarrhea, dizziness and pain in the injection site. The therapeutic effect can be fast (from the second day of treatment) and remain throughout treatment, making the patient's commitment to treatment easier. Specialized psychosocial intervention is advised ${ }^{44,45}$. One study performed with 624 patients showed that slow release naltrexone does not cause liver toxicity even in patients who kept drinking during the treatment, obtaining a higher reduction of GGT than placebo at weeks $4,8,12$, and 20 of treatment ${ }^{46}$.

Controlled studies performed with dually disordered alcohol-dependent patients have also confirmed the efficacy of naltrexone, obtaining a reduction in alcohol consumption, as well as in alcohol craving in schizophrenia ${ }^{47}$, in post-traumatic stress disorder ${ }^{48}$, and in major depression ${ }^{49}$. This suggests that naltrexone can be useful for the treatment of dually diagnosed alcoholdependent patients.

A few controlled studies with nalmefene have been performed to treat alcohol-dependence disorder. Some of them have found some efficacy in preventing heavy drinking ${ }^{50,51,52}$, and one controlled study has not confirmed its efficacy ${ }^{53}$. Two studies with positive 
efectuado con pacientes que presentaban depresión mayor, asociada al alcoholismo, no se encuentran diferencias entre el tratamiento con disulfiram o con naltrexona, pero los que tomaron disulfiram parece que experimentaron un menor craving que los que tomaron naltrexona ${ }^{48}$. En otro estudio, controlado para naltrexona, y abierto pero aleatorizado para disulfiram, los pacientes que presentaban un trastorno por estrés postraumático (asociado al alcoholismo), obtuvieron mejores resultados del tratamiento con naltrexona, con disulfiram o con la combinación de ambos fármacos que con placebo ${ }^{49}$. Lo cual sugiere que naltrexona puede ser de utilidad para el tratamiento de pacientes con diagnóstico dual.

Entre los estudios controlados efectuados con nalmefene para el tratamiento del alcoholismo, algunos han encontrado eficacia para prevenir la recaída al consumo excesivo de alcohol ${ }^{50,52,53}$, pero otro estudio no ha podido confirmar su eficacia ${ }^{50}$. Dos de los estudios en los que nalmefene resulta eficaz para reducir el número de días de consumo excesivo de alcohol se han efectuado con la modalidad de tratamiento intermitente, es decir, tomando medicación únicamente el día que el paciente se dispone a beber alcohol ${ }^{52,53}$. Los efectos adversos que se presentaron con mayor frecuencia que con placebo fueron las náuseas, insomnio, cansancio, mareo y malestar ${ }^{52}$.

\section{Características del tratamiento con antagonistas opioides}

El tratamiento con naltrexona puede conseguir a corto plazo una disminución del efecto reforzador del consumo de alcohol, un aumento de la sensación subjetiva de intoxicación y una reducción del efecto de pérdida de control. Y a largo plazo, una disminución del "craving" de alcohol, disparado por estímulos condicionados o por el estrés.

Diversos estudios controlados han comprobado la eficacia de naltrexona y nalmefene para reducir el número de días en que la persona toma alcohol, el número de consumiciones tomadas el día que bebe ${ }^{54,55,56}$; el número de días de consumo excesivo de alcohol y las cifras de los marcadores biológicos ALT y $\mathrm{GGT}^{52,53}$.

Pocos estudios han evaluado los posibles efectos de la retirada de naltrexona. 0'Malley y colaboradores ${ }^{57}$ comprobaron que las diferencias entre naltrexona y placebo desaparecian en el mes posterior a la retirada de naltrexona. Los estudios preclínicos efectuados con naltrexona comprobaron que los animales que no tomaron alcohol durante un tratamiento prolongado con naltrexona, retornaron a los niveles basales de consumo o incluso presentaron un consumo más elevado que el basal, cuando se les retiró la toma de naltrexona ${ }^{58}$.

Se ha postulado que tanto la abstención continuada de alcohol como el tratamiento prolongado con naltrexona podrían contribuir a dicho efecto de rebote del consumo excesivo o descontrolado de alcohol, tal vez debido a una regulación ascendente de los receptores opioides ${ }^{59}$. Al retirar el tratamiento con naltrexona, dicho aumento en la dispo- results for reducing the number of heavy drinking days have been performed with an intermittent treatment of nalmefene ${ }^{51,52}$. The most frequent adverse events were nausea, insomnia, fatigue, dizziness and malaise ${ }^{51}$.

\section{Characteristics of opioid antagonists treatment}

In the short term, naltrexone treatment can decrease the alcohol reinforcing effect, increase subjective intoxication, and reduce the loss of control effect. In the long term it can decrease alcohol conditioned craving.

Several controlled studies have shown the efficacy of naltrexone and nalmefene for reducing the days of alcohol consumption, the number of drinks per drinking day ${ }^{54,55,56}$; the number of heavy drinking days and the biological markers ALT and GGT 51,52 .

0 'Malley et al. ${ }^{57}$ proved that differences between naltrexone and placebo disappear during the month after naltrexone withdrawal, and preclinical studies have shown that the animals that remained abstinent during a long treatment with naltrexone came back to basal levels of consumption or they even showed a higher than basal consumption, when naltrexone was withdrawn ${ }^{58}$. This suggests that either continued sobriety or long treatment with naltrexone could be associated with a rebound effect on drinking and indicates that intermittent naltrexone treatment might possibly avoid this rebound effect.

Prolonged daily naltrexone treatment may produce an up regulation of opioid receptors ${ }^{59}$, and when naltrexone is withdrawn this increase in the availability of opioid receptors, in the absence of the blocking effect of naltrexone, could enhance the reinforcing effect of alcohol. These data support the hypothesis of Sinclair ${ }^{60}$ who postulated that opioid antagonists would obtain a better therapeutic efficacy in patients who keep on drinking alcohol than in those patients who stop drinking during weeks or months.

After an episode of sustained alcohol abstinence, alcohol-dependent monkeys and rats showed high levels of alcohol consumption. This has been called the catch up phenomenon, and it appears also in alcohol-dependent patients who have stopped drinking for weeks or months. It is characterized by a high alcohol craving after their first drink, which can drive them to lose control and relapse ${ }^{61}$.

Intermittent treatment with naltrexone could minimize its neuroadaptative impact on the opioid receptors and even reduce alcohol consumption more than continued treatment. In the short term, naltrexone can favor the recovery of self-control over drinking behavior, and in the long term, if the patient takes naltrexone everyday 
nibilidad de los receptores opioides, en ausencia del efecto de bloqueo de la naltrexona, potenciaría el efecto reforzador del consumo de alcohol. Estos datos apoyan la hipótesis de Sinclair ${ }^{60}$ el cual postuló que los antagonistas opioides conseguirian una mayor eficacia terapéutica en los pacientes que siguieran tomando bebidas alcohólicas, que en los que dejaran de tomarlas durante un tiempo y que un tratamiento intermitente con naltrexona podría evitar el mencionado efecto de rebote.

Los estudios preclínicos ya evidenciaron que, tras un período de abstención continuada de alcohol, las ratas y monos que habian desarrollado previamente una dependencia del alcohol presentaban elevados niveles de consumo (de alcohol). Es el llamado fenómeno del "catch up" que algunos han traducido como "recuperar el tiempo perdido". Este fenómeno, que aparece también en personas que presentan dependencia del alcohol y que han dejado de beber durante una temporada, consiste en que el primer día que prueban a tomar una bebida alcohólica pueden experimentar un intenso deseo de beber que les puede llevar a la pérdida de control y la recaída ${ }^{61}$.

Por tanto, un tratamiento intermitente con naltrexona podría minimizar su impacto neuroadaptativo sobre los receptores opioides e incluso conseguir una mayor reducción del consumo de alcohol que el tratamiento continuado. A corto plazo, naltrexona facilitaría la recuperación del autocontrol sobre la conducta de beber alcohol, y además a largo plazo, si el paciente toma naltrexona todos los días en los que va a ingerir bebidas alcohólicas, puede conseguir incluso una reducción progresiva del craving, y una extinción progresiva de la conducta condicionada al alcohol ${ }^{60,58,59}$. Estos autores proponen que el tratamiento con naltrexona sería más eficaz en los pacientes que presentan algún consumo de alcohol pero que han recibido instrucciones para evitar el consumo en forma de "atracones" ("binge drinking") ${ }^{62}$. También han propuesto que naltrexona debería ser administrada sin que el paciente haya dejado de beber, con la instrucción de tomar naltrexona sólo cuando anticipan que van a tomar bebidas alcohólicas y que dicho tratamiento intermitente se debería mantener de manera indefinida ${ }^{58}$, dado que la extinción sólo debilitaría las respuestas condicionadas que se generen al mismo tiempo que naltrexona bloquea el efecto reforzador del consumo de alcohol.

\section{Factores predictores de respuesta al tratamiento con naltrexona}

Se ha propuesto que determinadas características personales pueden ser predictoras de una mejor respuesta al tratamiento con naltrexona. La presencia de antecedentes familiares de alcoholismo, un elevado craving, la presencia de otro trastorno concomitante por abuso de sustancias, un mayor nivel de depresión, los rasgos de personalidad antisocial o la presencia del alelo Asp40 del receptor opioide mu (OPRM1 Asp 40). Pero otros autores no han confirmado alguno de ellos como la presencia de antecedentes familiares de acoholismo ${ }^{63}$. Parece que las personas con un consumo excesivo de alcohol que tienen el alelo Asp40 del receptor that he drinks alcohol, he can obtain even a progressive reduction of alcohol craving, and a progressive extinction of alcohol conditioned behavior ${ }^{60,58,59}$.

Naltrexone treatment could be more effective in patients who consume some alcohol but have learnt to avoid binge drinking ${ }^{62}$. If these patients have a low severity of alcohol-dependence and do not present withdrawal symptoms, alcohol detoxification will not be necessary ${ }^{54}$.

\section{Predictors of response to treatment with naltrexone}

It has been proposed that personal characteristics such as family history of alcoholism, a higher craving, a comorbid substance abuse disorder, a higher level of depression, antisocial personality traits or the presence of Asp40 allele of mu opioid receptor can be predictive of a better response to naltrexone treatment. Other authors have not confirmed some of these proposals, such as family history of alcoholism ${ }^{63}$. It seems that people who show a heavy drinking behavior and also have the allele Asp40 of mu opioid receptor show also a lower alcohol craving, a higher euphoria from the alcohol consumption and a higher decrease in the alcohol reinforcing effect, during treatment with naltrexone ${ }^{64}$.

Related to alcoholism typologies, North American authors have postulated that Babor type A would obtain a better response from naltrexone than type $B$, especially when naltrexone in doses of $100 \mathrm{mg} /$ day is associated with an intensive psychological intervention, such as cognitive behavior therapy. However, some European studies find the opposite data, because it would be the early onset alcohol-dependent patient belonging to Cloninger type II or Lesh types II and IV who would obtain a better response to naltrexone ${ }^{63}$.

There could also be gender differences, because studies with oral naltrexone (Hernández-Avila et al., $2006^{55}$ ) and with slow release naltrexone ${ }^{44}$ have not found good outcomes (superior to placebo) in women. However another study has shown that among women who drank during the treatment, those who took naltrexone, showed a higher number of days between the first and the next drinking days, in comparison with those who took placebo ${ }^{65}$. Baros, Latham and Anton ${ }^{66}$ have proposed that gender differences can be more related to sample size or outcome variables than to pharmacological or biological differences in the response to naltrexone. 
opioide mu presentan un menor craving de alcohol, un mayor efecto euforizante del consumo de alcohol y una mayor disminución del efecto reforzador del alcohol, durante el tratamiento con naltrexona ${ }^{64}$.

En relación a las tipologías del alcoholismo, autores americanos han postulado que el Tipo $A$ de Babor obtendría una mejor respuesta de naltrexona que el tipo $B$, pero algunos estudios europeos entran en contradicción con los americanos, ya que sería más bien el paciente alcohólico de inicio precoz, que correspondería al Tipo II de Cloninger, o a los tipos III y IV de Lesch, el que obtendría una mejor respuesta de naltrexona ${ }^{63}$.

También podria haber una diferencia de géneros, ya que estudios con naltrexona ora ${ }^{55}$ y también con naltrexona de liberación prolongada ${ }^{44}$ no han encontrado resultados superiores a placebo en mujeres. Sin embargo, un análisis posterior ha comprobado que entre las mujeres que bebieron durante el tratamiento, las que tomaban naltrexona presentaron un mayor número de días entre el primer consumo y los siguientes días de consumo de alcohol, que las que tomaron placebo ${ }^{65}$.

Baros, Latham y Anton ${ }^{66}$ proponen que el tamaño del efecto (del tratamiento con naltrexona) sería parecido en hombres y mujeres, lo cual sugiere que las diferencias encontradas en la respuesta al tratamiento con naltrexona pueden tener más que ver con el tamaño de la muestra o bien con las variables elegidas para evaluar los resultados del tratamiento que con diferencias farmacológicas o biológicas en la respuesta.

\section{Los Programas de Reducción Continuada del Con- sumo de Alcohol}

No beber alcohol todos los días y beber menos cantidad los dias que se bebe puede ser un objetivo realista para un paciente alcohólico de baja gravedad, si toma naltrexona los días en que bebe alcohol y si está motivado y comprometido para reducir la cantidad y la frecuencia de su consumo de alcohol, ya que todo ello va a producir una reducción progresiva de los signos cognitivos, emocionales y conductuales de la dependencia del alcohol. Sinclair en $1990^{60}$ postuló la hipótesis de la extinción, según la cual, si naltrexona bloquea el efecto reforzador del alcohol, repetir la experiencia de que cada nuevo consumo (de alcohol) ya no va seguido de un efecto reforzador, conduciría progresivamente a una disminución de los síntomas de la adicción al alcohol que tienen su base en el condicionamiento. De esta manera el paciente ya no piensa tanto en beber, ya no se siente obligado a beber en determinadas situaciones (como por ejemplo cuando pasa por delante de un bar en el que antes siempre entraba a beber) y puede ir recuperando la libertad de escoger entre tomar o no tomar alcohol.

Algunos estudios han demostrado que la toma de naltrexona o nalmefene, únicamente el día que la persona se dispone a tomar bebidas alcohólicas, puede ayudarle a reducir el consumo de alcohol ${ }^{54,56}$. Otros estudios efectuados con antagonistas opioides, tanto con naltrexona (50

\section{Sustained reduction programs of alcohol drinking}

Not drinking everyday and drinking fewer drinks per drinking day can be a realistic goal for low severity alcoholdependent patients if they take naltrexone every day that they drink alcohol, and if they are motivated and committed to reduce the quantity and frequency of alcohol drinking.

Cognitive, emotional and behavioral signs of alcoholdependence will probably decrease progressively if the patient takes naltrexone every day he drinks alcohol. In 1990 Sinclair ${ }^{60}$ postulated the hypothesis of extinction, proposing that the blocking effect of naltrexone on alcohol reinforcing effects may produce a decrease in conditioned addictive behavior. The patient would think less and less about drinking alcohol, will not feel compelled to drink in conditioned situations (such as when he is near a bar where he always went in to have a drink), and he may progressively recover freedom to choose between drinking or not drinking alcohol.

Targeted naltrexone treatment has achieved a significant reduction of alcohol consumption, both with naltrexone ${ }^{56}$ and with nalmefene ${ }^{52}$. Naltrexone $(50 \mathrm{mg} /$ day) reduces drinks per day and drinks per drinking day ${ }^{56}$ while nalmefene $(20 \mathrm{mg} /$ day the first 2 weeks and $40 \mathrm{mg} /$ day form the third week an on) reduces the intensity and frequency of alcohol consumption, the number of drinks per day, and the total amount of alcohol more than placebo ${ }^{51}$.

Therefore a change of paradigm in the treatment of low severity alcohol-dependence is possible, starting without a previous detoxification and oriented to a continued reduction of drinking, because this goal (continued reduction) can be associated with substantial improvement of possible medical, psychiatric, social and legal consequences of drinking.

\section{Long term advantages of continued reduction of alcohol consumption}

When a person becomes conscious that he cannot control alcohol intake he or she makes the radical decision of stop drinking but, sooner or later, they will try to drink a little bit to check whether after an abstinence period, they have recovered their ability to control consumption. This alternation between noncontrol and hypercontrol, frequently seen in human behavior, can have some relationship with the opioid neurotransmission system and it includes consummatory behaviors such as feeding, sexual behavior and addictive behaviors.

It has not always been possible for humans to eat several times a day. Sometimes there has not been enough food available to eat everyday. Food privation 
$\mathrm{mg} / \mathrm{día})^{56}$ como con nalmefene $(20 \mathrm{mg} / \mathrm{dia}$, las 2 primeras semanas y $40 \mathrm{mg} /$ día a partir de la tercera semana), consiguen una reducción superior al placebo, tanto de la intensidad como de la frecuencia de consumo de alcohol, del número de consumiciones por día de consumo, y del consumo total de alcohol ${ }^{51}$.

A partir de este punto se produce un cambio de paradigma en el tratamiento de los pacientes alcohólicos de baja gravedad, ya que puede iniciarse sin que el paciente tenga que dejar de beber por completo y el criterio de recuperación se basa en objetivo terapéutico de que si una persona reduce de manera significativa y continuada su consumo de alcohol, va a experimentar también una mejoría sustancial de las posibles consecuencias médicas, psiquiátricas, familiares, laborales, sociales y legales de su alcoholismo.

\section{Ventajas a largo plazo de la reducción continuada del consumo de alcohol}

Cuando una persona toma conciencia de que no puede controlar el consumo de alcohol puede tomar la decisión radical de dejar de beber, pero tarde o temprano, intentará hacer un pequeño consumo de alcohol, para comprobar si, tras un período de abstención, ha recuperado su capacidad para controlar el consumo. Esta alternancia entre el descontrol y el hipercontrol que aparece con frecuencia en el comportamiento humano, puede tener alguna relación con el funcionalismo del sistema opioide y forma parte del grupo de conductas consumatorias, como la alimentaria, la sexual y las conductas adictivas.

En tiempos pretéritos el hombre no disponía de alimentos para comer varias veces al día. En ocasiones, ni siquiera podía comer todos los días. Podía atravesar incluso largas temporadas de privación de alimentos, que se alternaban con otras de mayor abundancia y disponibilidad. Una de las funciones del sistema opioide sería la de potenciar las conductas consumatorias, relacionadas con la alimentación o la conducta sexual, con la finalidad de compensar otras temporadas de escasez o privación. La conducta de alimentación y sexual son decisivas para la supervivencia individual y también de la especie, respectivamente, y la activación del sistema opioide desde el inicio de dichas conductas, va a producir una importante potenciación motivacional que facilita la consumación e incluso la repetición de dicha conducta, llegando a interferir en el autocontrol sobre la misma. Los efectos reforzadores de las conductas consumatorias contribuirian a una facilitación de su aprendizaje, ya que promoverían el desarrollo de un condicionamiento apetitivo que consolidaría la motivación para el consumo cada vez más frecuente, con mayor rapidez y en mayores cantidades ${ }^{67}$.

Cuando una persona ha desarrollado dependencia del alcohol, los estímulos condicionados pueden activar el sistema opioide y disparar el craving y el deterioro del autocontrol sobre la conducta de beber. Además, el descontrol sería tanto mayor cuanto más tiempo hubiera transcurrido desde el anterior consumo, de manera parecida a lo que podría suceder a una persona que tras la deprivación de agua, comi- seasons alternated with seasons that had greater food availability. A function of the opioid system would be to potentiate consummatory behavior that may be food related or sexually related, with the goal of compensating privation seasons.

Eating and sexual behaviors are essential for individual survival and also for species survival. Opioid system activation from the beginning of a feeding behavior can trigger the motivation that may facilitate the completion of this behavior. The reinforcing effects of consummatory behaviors will contribute to progressive learning of these behaviors, favoring the incentive for appetitive conditioning that consolidates motivation and increases the performance of these behaviors ${ }^{67}$.

When a person has developed an alcohol-dependence disorder, conditioned cues may activate the opioid system, induce alcohol craving and impair self-control regarding alcohol drinking behavior.

Impaired control over drinking is usually higher when it has been a long time since the last drinking occasion. This has some resemblance to situations of water, food or sexual activity deprivation. However, an essential difference could be that feeding or sexual behavior usually leads to satiety or surfeit effects, while alcohol drinking and similar addictive behaviors do not usually produce satiety but cause an appetitive effect, and one drink increases the craving for another drink, and so on.

After a period of abstinence, it is likely that alcoholdependence patients will try to drink again. They may then lose control and drink heavily again. In bingeeating disorders, the patient tries to control their weight by strict dieting or by purgative strategies. However, this pendular movement that goes between uncontrol and hypercontrol progressively worsens the problem. Repeating this alternance between abstinence and relapse might characterize the evolution of many addictive behaviors that could be blocked effectively.

Naltrexone treatment may improve some behavioral symptoms, such as loss of control, from the onset of treatment. Other motivational symptoms, such as craving, obsession for drinking, and searching and approaching behaviors such as entering bars may improve in the long term.

Intermittent treatment reduces naltrexone's hepatotoxicity risk because the patient does not need to take the medication everyday, thus allowing doses of up to $100 \mathrm{mg} /$ day, as may be necessary in some patients. 
da o actividad sexual, experimentará una intensa y repetitiva conducta consumatoria, hasta llegar a la saciedad y al empacho.

Tras un período de abstención, lo más probable es que el paciente alcohólico reinicie su consumo, pierda el control y vuelva a beber en exceso. En el "binge eating" o trastorno por atracones de comida, en el que la persona intenta controlar su peso mediante dietas estrictas o bien estrategias purgativas, este movimiento pendular que fluctúa entre el descontrol y el hipercontrol conduce progresivamente a un empeoramiento del problema. Por tanto, la repetición de esta alternancia entre temporadas de abstención y recaídas con pérdida de control podría ser la evolución característica de muchas conductas adictivas, pero puede ser eficazmente bloqueada.

El tratamiento con naltrexona puede mejorar el autocontrol y consigue algo parecido al modelo médico de tratamiento de enfermedades, en el cual un fármaco específico neutraliza algunos síntomas conductuales (la pérdida de control), desde el inicio del tratamiento y a largo plazo incluso otros síntomas motivacionales como el craving, la "obsesión" por beber y las conductas de búsqueda y aproximación, tales como entrar a los bares.

El tratamiento intermitente con naltrexona reduce el riesgo de hepatotoxicidad, ya que el paciente no necesita tomar el medicamento todos los días, lo cual facilita también que se puedan utilizar dosis de hasta $100 \mathrm{mg} /$ dia, que en algunos pacientes van a ser necesarias.

El tratamiento prolongado con naltrexona puede facilitar que el paciente comprenda los importantes beneficios de una reducción sustancial del consumo de alcohol, tanto en cantidad como en frecuencia. Cuando comprueba que al reducir el consumo de alcohol consigue la remisión de las consecuencias del consumo excesivo (previo), dado que ya no obtiene el mismo efecto reforzador del consumo de alcohol, es posible que remita su "obsesión" por beber, que sea más ecuánime al sopesar pros y contras del consumo de alcohol, que limite su consumo a determinadas ocasiones, es decir que recupere la libertad para decidir cuándo va o no va a tomar bebidas alcohólicas. Esta libertad puede parecer poco importante para las personas que no han tenido dificultades para controlar su consumo de alcohol, pero resulta decisiva cuando se ha perdido y puede ser uno de los factores que contribuyan a incrementar la "obsesión" por beber y los síntomas de duelo, cuando se tiene que dejar de beber, que a algunos pacientes les puede llevar a la depresión y/o a la recaída.

\section{Limitaciones de los programas de reducción del consumo de alcohol}

La motivación del paciente es importante para resolver cualquier problema de salud pero resulta fundamental cuando se trata de una conducta adictiva y puede ser decisiva para que el tratamiento con antagonistas opioides resulte eficaz.
Prolonged naltrexone treatment can help the patient to understand the benefits of substantially reducing alcohol consumption in quantity and frequency. Once patients verify that alcohol is no longer reinforcing for them, and once they have improved, they will have the opportunity to be more rational, assess the pros and cons about alcohol consumption, limit consumption to special occasions, and recover their freedom to decide when to drink and when not to drink. This freedom does not seem important for people who do not need to stop drinking, but it can be essential if it has been lost. Besides, it can contribute to increasing the obsession for drinking and the symptoms of grief and depression that may increase relapse risk.

\section{Limitations of programmes to reduce drinking}

Patient motivation is important for recovery in any health problem but it is essential in the process of recovery from an addictive behavior and may be decisive for the efficacy of opioid antagonists treatment

Cognitive impairment and poor compliance with medication can hinder the efficacy of the treatment. For example, if patients do not take the medication every time that they drink alcohol, appetitive conditioning can be reinstated, increasing the probability that loss of control over drinking will reappear.

A higher severity of alcohol-dependence, with severe alcohol withdrawal symptoms or comorbid psychiatric or addictive disorders, can also be important limitations, because negative reinforcing effects may override naltrexone effects. Opioid antagonists can block positive reinforcing effects of alcohol drinking but they cannot block the relief effect of alcohol, over anxiety, tension, panic, phobia, insomnia, dysphoria, posttraumatic stress or alcohol withdrawal symptoms.

As commented above in the neurochemical crossroad of midbrain VTA there are other relevant neurotransmitters that are related to alcohol craving and also to loss of control. Therefore, the opioid receptor activation is only a part of the impact of alcohol drinking on the brain, and this impact may be different in each person, depending on specific genes that can modify opioid receptor function.

When the therapeutic response to opioid antagonists is insufficiently high, even though treatment compliance is good and the therapeutic procedure is correct, dose increase or combining the opioid antagonist with other medications (that could be active on other involved neurotransmission systems) could be useful to optimize the treatment outcome. In addition, if the patient has another psychiatric or addictive 
Tanto el deterioro cognitivo, que puede dificultar el adiestramiento del paciente, como otros factores que interfieren en el cumplimiento de la oportuna toma de medicación, pueden ser cruciales para la eficacia del tratamiento. Por ejemplo, cada vez que el paciente beba (alcohol) sin haber tomado naltrexona se producirá una reintensificación de su condicionamiento apetitivo, aumentando la probabilidad de que reaparezca la pérdida de control sobre su consumo de alcohol.

Una mayor gravedad de la dependencia va a ser también una importante limitación que puede disminuir el resultado del tratamiento. Los pacientes que tienen un claro síndrome de abstinencia del alcohol y los que presentan trastornos psiquiátricos o adictivos comórbidos pueden obtener un importante efecto reforzador negativo del consumo de alcohol. Los antagonistas opioides bloquean los efectos reforzadores positivos, pero probablemente no pueden revertir el condicionamiento evitativo que se produce por la repetición del efecto de alivio de abstinencia o de automedicación de los síntomas psiquiátricos intensos (ansiedad, tensión, angustia, fobias, insomnio, disforia, estrés postraumático, etc.). Si el objetivo del consumo es únicamente la automedicación de síntomas psiquiátricos, es posible que naltrexona no sea tan eficaz como si el efecto preferente que paciente busca es el efecto reforzador positivo del alcohol.

Como se ha comentado, en la encrucijada neuroquímica del ATV del mesencéfalo intervienen otros neurotransmisores relevantes, tanto para el craving como para la pérdida de control. El papel que va a jugar la neurotransmisión opioide es sólo una parte del impacto del consumo de alcohol, que puede ser diferente en cada persona, incluso en relación con los determinantes genéticos del funcionalismo de sus receptores.

Por tanto, en aquellos pacientes cuya respuesta terapéutica a los antagonistas opioides sea insuficiente, a pesar de un buen cumplimiento y de un procedimiento terapéutico correcto, convendrá potenciar la prescripción farmacológica tal vez aumentando las dosis, o bien asociando fármacos no adictivos que actúen sobre los otros sistemas de neurotransmisión implicados, con la finalidad de optimizar el resultado del tratamiento. Naturalmente, tanto los trastornos psiquiátricos como la adicción a otras sustancias tienen otro tratamiento especializado, que conviene asociar al tratamiento de la dependencia del alcohol.

\section{CONCLUSIONES}

1. Los pacientes alcohólicos graves o los que presentan una grave comorbilidad médica, psiquiátrica o adictiva, requieren un programa de tratamiento orientado hacia la abstención continuada de alcohol.

2. La reducción continuada (en cantidad y frecuencia) del consumo de alcohol, por debajo de los límites del consumo de riesgo, podría ser otra manera de alcanzar la remisión clínica para el trastorno por dependencia del alcohol. disorder, specialized treatment for this other disorder should be associated with the treatment of alcohol dependence.

\section{CONCLUSIONS}

1. High severity alcohol-dependent patients and those who show a severe medical, psychiatric or addictive comorbidity need a treatment oriented to the sustained abstinence of alcohol.

2. A sustained reduction (in quantity and frequency) in alcohol consumption, below the limits of risk drinking, could be another form of sustained remission for alcoholdependence disorder.

3. Targeted naltrexone may obtain a sustained reduction of drinking if the patient takes this medication every day that he drinks alcohol.

4. The last large study on the treatment of alcoholdependence disorder (COMBINE study) has confirmed the efficacy and safety of a daily oral dose of $100 \mathrm{mg}$ of naltrexone. Different patients may require a different dose.

5. When an alcohol-dependent patient drinks again, after an abstinence period, he will highly likely drink heavily. Naltrexone may prevent occasional alcohol consumption progressing to a relapse.

6. Naltrexone treatment may be more useful in the treatment programs oriented to reduction of drinking than in abstinence-oriented programs.

7. Blood tests should be carried out before naltrexone treatment is started and liver function tests should be done throughout treatment. Severe liver disease would be a counter-indication for people requiring treatment with opioid pain-relievers or for those showing active opioid dependence.

8. Further randomized controlled trials are needed to enhance initial evidence about the effectiveness of targeted treatment with opioid receptor antagonists.

\section{DISCLOSURE STATEMENT}

Dr. Josep Guardia-Serecigni has participated as principal investigator in several clinical trials with medications for the alcohol-dependence treatment. Promoters of these clinical trials have given economic support to the Research Institute of the Santa Creu and Sant Pau Hospital, which is the institutional setting where these clinical trials have been performed. 
3. El tratamiento intermitente con naltrexona puede conseguir una reducción continuada del consumo de alcohol, siempre que esta se tome todos los días en los que el paciente bebe alcohol.

4. El último gran estudio para el tratamiento de la dependencia del alcohol (estudio COMBINE) ha confirmado la eficacia y la seguridad de la toma diaria de $100 \mathrm{mg}$ de naltrexona. Diferentes pacientes pueden requerir dosis distintas.

5. Cuando una persona que tiene dependencia del alcohol vuelve a beber, tras una temporada de abstención (de alcohol), tiene más probabilidades de perder el control. Naltrexona puede prevenir que un consumo ocasional de alcohol se acabe convirtiendo en una recaída.

6. Naltrexona puede ser más útil en los programas orientados hacia la reducción del consumo de alcohol que en aquellos que tienen por objetivo su abstención continuada.

7. El tratamiento con naltrexona requiere una evaluación previa y también periódica del funcionalismo hepático y está contraindicado en pacientes hepatópatas graves y en los que requieren tratamiento con analgésicos opioides o que presentan dependencia de opioides activa.

8. Futuros estudios controlados deberían ser llevados a cabo para ampliar las evidencias preliminares sobre la eficacia del tratamiento intermitente con fármacos antagonistas de los receptores opioides.

\section{DECLARACIÓN de INTERESES}

El Dr. Josep Guardia Serecigni ha participado como investigador principal en diversos ensayos clínicos con medicamentos para el tratamiento de la dependencia del alcohol. Los promotores de dichos ensayos clínicos han dado apoyo económico al Instituto de Investigación del Hospital de la Santa Creu y Sant Pau de Barcelona, que es el marco institucional donde se han efectuado los mencionado ensayos clínicos.

\section{REFERENCIAS}

1. Brandon $T H$, Vidrine JL, Litvin EB. Relapse and relapse prevention. Annu Rev Clin Psicol. 2007; 3: 257-284.

2. Sinha R. The role of stress in addiction relapse. Curr Psychiatry Rep 2007; 9: 388-395.

3. Kalivas PW, Volkow ND. The neural basis of addiction: a pathology of motivation and choice. Am J Psychiatry 2005; 162: 1403-1413.

4. Guardia Serecigni J, Jiménez Arriero MA, Pascual Pastor F, Flórez Menéndez G, Contel Guillamón M. Alcoholismo. Guía clínica de Socidrogalcohol basada en la evidencia científica. 2a Edición. SOCIDROGALCOHOL. Barcelona. 2008.

5. Clapp P, Bhave SV, Hoffman PL. How adaptation of the brain to alcohol leads to dependence. A pharmacological perspective. Alcohol Research \& Health 2008; 31: 310-339.

6. Guardia Serecigni J, Surkov S, Cardús M. Neurobiología de la Adicción. En: César Pereiro (Editor). Manual de Adicciones para médicos especialistas en formación. SOCIDROGALCOHOL. Barcelona. 2010. (p. 37-130).

7. Rehm J, Room R, Monteiro M, Gmel G, Graham K, Rehn T, Sempos CT, Frick U, Jernigan D. Alcohol. In: WHO (ed.) Comparative quantification of health risks: Global and regional burden of disease due to selected major risk factors. Geneva 2004.

8. World Health Organization. The World Health Report 2002. Reducing risks, promoting healthy life. Geneva 2002.

9. Kranzler HR, Babor TF, Lauerman RJ. Problems associated with average alcohol consumption and frequency of intoxication in a medical population. Alcohl Clin Exp Res 1990; 14: 119-126.

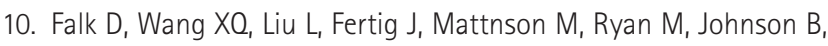
Stout $R$, Litten RZ. Percentage of subjects with no heavy drinking days: evaluation as an efficacy endpoint for alcohol clinical trials. Alcohol Clin Exp Res 2010; 34: 2022-20343.

11. Hughes K, Bellis MA, Whelan G, Calafat A, Juan M, Blay N. Alcohol, Drugs, Sex and violence: Health risks and consequences in young British holidaymakers to the Balearics. Adicciones 2009; 21: 265278.

12. Del Río, MC, Gómez J, Sancho M, Alvarez J. Alcohol, illicit drugs and medicinal drugs in fatally injured drivers in Spain between 1991 and 2000. Forensic Science International. 2002; 127: 63-70.

13. Gómez MT, Del Río MC, Álvarez FJ. Alcohol y accidentes laborales en España: revisión bibliográfica, 1995-2001. Trastornos Adictivos 2002; 4: 244-255

14. Guardia Serecigni J. Is alcohol really good for health? Adicciones 2008; 20: 221-236.

15. Anton RF. Naltrexone for the management of alcohol dependence. N Eng Med J 2008; 359: 715-721.

16. Work Group on Substance Use Disorders. Treatment of patients with substance use disorders, second edition. American Psychiatric Association Practice Guidelines. Am J Psychiatry. 2007; 164,4 . 
17. Guardia Serecigni J. Introducción a avances en el tratamiento farmacológico del alcoholismo y de la enfermedad adictiva, una vez finalizado el tratamiento de la abstinencia aguda. JANO Psiquiatría. Barcelona 2009; 4: 5-8.

18. Swift R. Emergency Management of Alcohol Abuse and Dependence. In: Johnson, Ruiz \& Galanter (Eds.). Handbook of Clinical Alcoholism Treatment. Lippincott Williams \& Wilkins. Philadelphia. 2003. (p. 140-149)

19. Anton RF, O'Malley SS, Ciraulo DA, Cisler RA, Couper D, Donovan DM, Gastfriend DR, Hosking JD, Johnson BA, LoCastro JS, Longabaugh $R$, Mason BJ, Mattson ME, Miller WR, Pettinati HM, Randall CL, Swift R, Weiss RD, Williams LD, Zweben A. COMBINE Study Research Group. Combined pharmacotherapies and behavioral interventions for alcohol dependence - the COMBINE study: a randomized controlled trial. JAMA 2006; 295: 2003-2017.

20. Juarez J, De Tomasi Eliana B. Alcohol consumption is enhanced after naltrexone treatment. Alcohol Clin Exp Res 2007; 31: 260264.

21. Naranjo CA, Dongier M, Bremner KE. Long-acting injectable bromocriptine does not reduce relapse in alcoholics. Addiction 1997; 92: 969-978.

22. Guardia J, Segura I, Gonzalvo B, Iglesias L, Roncero C, Cardús M, Casas M. A Double-blind, Placebo-controlled study of Olanzapine in the Treatment of Alcohol-Dependece Disorder. Alcohol Clin Exp Res. May 2004; 28: 736-745.

23. Guardia J, Roncero C, Galan J, Gonzalvo B, Burguete T, Casas M. A double-blind, placebo-controlled, randomized pilot study comparing quetiapine with placebo, associated to naltrexone, in the treatment of alcohol-dependent patients. Addictive Behaviors. 2011; 36: 265-269.

24. Guardia Serecigni J. Avances en el tratamiento farmacológico del alcoholismo y de la enfermedad adictiva, una vez finalizado el tratamiento de la abstinencia aguda. JANO 2009; 4: 21-33.

25. Guardia J. Naltrexona en el tratamiento de la dependencia del alcohol. Psiquiatría Biológica 1998; 5: 35-44.

26. Anton RF, Drobes DJ, Voronin K, Durazo-Avizu R, Moka D. Naltrexone effects on alcohol consumption in a clincal laboratory paradigm: temporal effects of drinking. Psychopharmacology (Berl) 2004;173: 32-40.

27. Drobes DJ, Anton RF, Thomas SE, Voronin K. Effects of naltrexone and nalmefene on subjective response to alcohol among nontreatment-seeking alcoholics and social drinkers. Alcohol Clin Exp Res 2004; 28: 1362-1370.

28. Davidson D, Palfai T, Bird Ch, Swift R. Effects of naltrexone on alcohol self-administration in heavy drinkers. Alcohol Clin Exp Res 1999; 23: 195-203.

29. Guardia J, Caso C, Arias F, Gual A, Sanahuja J, Ramírez M, Mengual I, Gonzalvo B, Segura L, Trujols J, Casas M. A doubleblind, placebo-controlled study of naltrexone in the treatment of alcohol-dependence disorder. Results from a multicenter clinical trial. Alcohol Clin Exp Res. 2002; 26: 1381-1387.
30. Bouza C, Magro A, Muñoz A, Amate JM. Efficacy and safety of naltrexone and acamprosate in the treatment of alcohol dependence: a thematic review. Addiction 2004; 99: 811-828.

31. Pettinati HM, O'Brien $C P$, Rabinowitz AR, Wortman SP, Oslin DW, Kampman KM, Dackis CA. The status of naltrexone in the treatment of alcohol dependence: specific effects on heavy drinking. J Clin Psychopharmacol 2006; 26: 610-625.

32. Srisurapanont $M_{1}$ Jarusuraisin N. Naltrexone for the treatment of alcoholism: a meta-analysis of randomized controlled trials. Int J Neuropsychopharmacol 2005; 8: 267-280.

33. Rösner $S$, Hackl-Herrweth $A$, Leucht $S$, Vecchi $S$, Srisurapanant $M$, Soyka M. Opioid antagonists for alcohol dependence. Cochrane Database Syst Rev 2010; 12: CD001867.

34. Kranzler HR, Modesto-Lowe V, Van Kirk J. Naltrexone vs. nefazodone for the treatment of alcohol-dependence. A placebocontrolled trial. Neuropsychopharmacology 2000; 22: 493-503.

35. Krystal JH, Cramer JA, Krol WF, Kirk GF, Rosenheck RA, for the Veterans Affairs Naltrexone Cooperative Study 425 Group. Naltrexone in the treatment of alcohol dependence. N Engl J Med 2001; 345: 1734-1739.

36. Oslin DW, Lynch KG, Pettinati HM, Kampman KM, Gariti $P$, Gelfand L, Ten Have T, Wortman S, Dundon W, Dackis C, Volpicelli $J R, 0$ Brien Cp. A placebo-controlled randomized clinical trial of naltrexone in the context of different levels of psychosocial intervention. Alcohol Clin Exp Res 2008; 32: 1299-1308.

37. Gueorguieva $R$, Wu R, Pittman B, Cramer J, Rosenheck RA, O'Malley SS, Krystal JH. New insights into the efficacy of naltrexone based on trajectory-based reanalyses of two negative clinical trials. Biol Psychiatry 2007; 61: 1290-1295.

38. Chick J, Anton R, Checinski $K_{1}$ Croop R, Drummond DC, Farmer R, Labriola D, Marshall J, Moncrieff J, Morgan MY, Peters T, Ritson B: A multicentre, randomized, double-blind, placebo-controlled trial of naltrexone in the treatment of alcohol dependence or abuse. Alcohol \&t Alcoholism 2000; 35: 587-593.

39. Anton RF. Naltrexone for the management of alcohol dependence. N Eng Med J 2008; 359: 715-721.

40. Killeen TK, Brady KT, Gold PB, Simpson KN, Faldowski RA, Tyson C, Anton RF. Effectiveness of naltrexone in a community treatment program. Alcohol. Clin. Exp. Res. 2004; 28: 1710-1716.

41. Ray LA, Krull JL, Leggio L. The effects of naltrexone among alcohol non-abstainers: results from the COMBINE Study. Frontiers in Psychiatry 2010; 1: 1-6.

42. Arias Horcajadas F, Ochoa Mangado E, Torres Hernández MA y grupo de estudio observacional de la dependencia alcohólica (GEODA) Trastornos Adictivos 2000; 2: 194-200.

43. Croop RS, Faulkner EB, Labriola DF. The safety profile of naltrexone in the treatment of alcoholism. Results from a multicenter usage study. Arch. Gen. Psychiatry 1997; 54: 1130-1135.

44. Garbutt JC, Kranzler HR, O'Malley SS, Gastfriend DR, Pettinati HM, Silverman BL, Loewy JW, Ehrich EW for the Vivitrex Study Group. Efficacy and tolerability of long-acting injectable naltrexone for alcohol dependence. JAMA 2005; 293: 1617-1625. 
45. Ciraulo DA, Dong O, Silverman BL, Gastfriend DR, Pettinati HM. Early treatment response in alcohol dependence with extendedrelease naltrexone. J Clin Psychiatry 2008.

46. Lucey MR, Silverman BL, Illeperuma A, O'Brien CP. Hepatic safety of once-monthly injectable extended-release naltrexone adminstered to actively drinking alcoholics. Alcohol Clin Exp Res 2008; 32: 498-504.

47. Petrakis IL, O'Malley S, Rounsaville B, Poling J, McHugh-Strong C, Krystal JH, VA Naltrexone Study Collaboration Group. Naltrexone augmentation of neuroleptic tratment in alcohol abusing with schizophrenia. Psychopharmacology (Berl) 2004; 172: 291-297.

48. Petrakis IL, Poling J, Levinson C, Nich C, Carroll K, Ralevski E, Rounsaville $\mathrm{B}$. Naltrexone and disulfiram in patients with alcohol dependence and comorbid post-traumatic stress disorder. Biol Psychiatry 2006; 60: 777-783.

49. Petrakis I, Ralevski E, Nich C, Levinson C, Carroll K, Poling J, Rounsaville B, VA VISIN I MIRECC Study Group. Naltrexone and disulfiram in patients with alcohol dependence and current depression. J Clin Psychopharmacol 2007; 27: 160-165.

50. Masson BJ, Salvato FR, Williams LD, Ritvo EC, Cutler RB. A doubleblind placebo-controlled study of oral nalmenfene for alcohol dependence. Arch Gen Psychiatry 1999; 56: 719-724.

51. Karhuvaara S, Simojoki K, Virta A, Rosberg M, Loyttiniemi $E$, Nurminen T, Kallio A, Makela R. Targeted nalmefene with simple medical management in the treatment of heavy drinkers: a randomized double-blind placebo-controlled multicenter study. Alcohol Clin Exp Res 2007; 31: 1179-1187.

52. Arias AJ, Armeli S, Glernter J, Covault J, Kallio A, Karhuvaara S, Koivisto T, Mäkelaä R, Kranzler HR. Effects of opioid receptor gene variation on targeted nalmefene treatment in heavy drinkers. Alcohol Clin Exp Res 2008, Jun 3.

53. Anton RF, Pettinati $H$, Zweben $A$, Kranzler HR, Johnson B, Bohn MJ, McCaul ME, Anthenelli R, Salloum I, Galloway G, Swift R, Gastfriend D, Kallio A, Karhuvaara S. A mulisite dose ranging study of nalmefene in the treatment of alcohol dependence. J Clin Psychopharmacol 2004; 24: 421-428.

54. Heinala P, Alho H, Kiianmaa K, Lonnqvist J, Sinclair JD. Targeted use of naltrexone without prior detoxification in the treatment of alcohol dependence: a factorial double-blind, placebo-controlled trial. J Clin Psychopharmacol 2001; 21: 287-292.

55. Hernández-Ávila CA, Song Ch, Kou L, Tennen H, Armeli S, Kranzler HR. Targeted versus daily naltrexone: second analysis of effects on average daily drinking. Alcohol Clin Exp Res 2006; 30: 860865.

56. Kranzler HR, Tennen H, Armeli S, Chan G, Covault J, Arias A, Oncken C. Targeted naltrexone for problem drinkers. J Clin Psychopharmacol 2009; 29: 350-357.

57. O'Malley SS, Jaffe AJ, Chang G, Rode S, Schottenfeld R, Meyer RE, Rounsaville B. Six-month follow-up of naltrexone and psychotherapy for alcohol dependence. Arch Gen Psychiatry 1996; 53: 217-224.
58. Sinclair JD. Evidence about the use of naltrexone and for different ways of using it in the treatment of alcoholism. Alcohol \&t Alcoholism 2001; 36: 2-10.

59. Parkes $H$, Sinclair JD. Reduction of alcohol drinking and upregulation of opioid receptors by oral naltrexone in AA rats. Alcohol 2000; 21: 215-221.

60. Sinclair JD. Drugs to decrease alcohol drinking. Ann Med 1990; 22: 357-362.

61. Guardia J, Prat G, Casas M. El sistema opioide como modulador del consumo de alcohol. Psiquiatría Biológica. 1998; 5: 25-34.

62. Sinclair JD, Alho H. Naltrexone for alcohol dependence. N Eng J Med 2002; 346: 1329-1331.

63. Bogenschutz MP, Tonigan JS, Pettinati HM. Effects of alcoholism typology on response to naltrexone in the COMBINE study. Alcohol Clin Exp Res 2009; 33:10-18.

64. Ray LA, Hutchinson KE. Effects of naltrexone on alcohol sensitivity and genetic moderators of medication response: a double-blind placebo-controlled study. Arch Gen Psychiatry 2007; 64: 10691077.

65. O'Malley SS, Sinha R, Grilo CM, Capone Ch, Farren CK, McKee $S A$, Rounsaville BJ, Ran W. Naltrexone and cognitive behavioral coping skills therapy for the treatment of alcohol drinking and eating disorder features in alcohol-dependent women: a randomized controlled trial. Alcohol Clin Exp Res 2007; 31: 625634.

66. Baros AM, Latham PK, Anton RF. Naltrexone and cognitive behavior therapy for the treatment of alcohol dependence: do sex differences exist? Alcohol Clin Exp Res 2008; 32: 771-776.

67. Reid LD. Opioids, bulimia, and alcohol abuse and alcoholism. Springer-Verlag. New Cork. 1990. 